\title{
Correction to: Nonlinear dynamics of the Burgers' equation and numerical experiments
}

\section{Ali Başhan ${ }^{1}$ (])}

Published online: 12 June 2021

(c) Islamic Azad University 2021

\section{Correction to: Mathematical Sciences \\ https://doi.org/10.1007/s40096-021-00410-8}

Unfortunately, the references were updated incorrectly and now the original article has been corrected.

Publisher's Note Springer Nature remains neutral with regard to jurisdictional claims in published maps and institutional affiliations.

The original article can be found online at https://doi.org/10.1007/ s40096-021-00410-8.

\footnotetext{
Ali Başhan

alibashan@gmail.com

1 Department of Mathematics, Faculty of Science and Art, Zonguldak Bulent Ecevit University, 67100 Zonguldak, Turkey
} 